\title{
Surgical Treatment of Mild Hip Dysplasia in Combination with Pembersaland Femoral Osteotomy
}

\author{
Hafif Kalça Displazisinin Pembersal ve Femoral Ostetomi Kombinasyonlu Cerrahi Tedavisi
}

${ }^{1}$ Department of Orthopaedicsand Traumatology, Eskisehir Osmangazi University

Faculty of Medicine, Eskisehir, Turkey

${ }^{2}$ Department of Orthopaedicsand Traumatology, Gazi UniversityFaculty of Medicine, Ankara, Turkey

\section{${ }^{1}$ Cuneyd Gunay, ${ }^{2}$ Hakan Atalar, ${ }^{2}$ Coskun Ulucakoy, ${ }^{2}$ Elshan Najafov, ${ }^{2}$ Sacit Turanli}

\section{Abstract}

The aim of this study was to show the clinical and radiographic mid-term results of Pembersal and femoral osteotomy withoutopen redu tion in patients with mild dysplasia of the hip joint. This case series included 13 Developmental Dysplasia of the Hip (DDH) patients (13 hips), who underwent a combination of Pembersal and femoral osteotomy without open reduction between January 2014 and June 2020. The patients comprised 12 females (93\%) and 1 male (8\%), with a mean age at surgery of

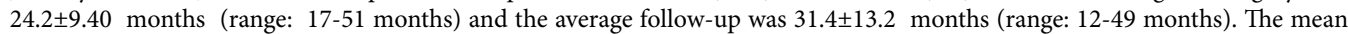
acetabular index decreased significantly from $36.6^{\circ} \pm 4.87^{\circ}$ (range: $30^{\circ}-46^{\circ}$ ) preoperatively, to $18^{\circ} \pm 1.41^{\circ}\left(\right.$ range: $15^{\circ}-21^{\circ}$ ) at the final follow-up examination $(\mathrm{p}<0.001)$. Avascular necrosis $(\mathrm{AVN})$ was not seen in any patient. The results showed that this kind of surgical procedure seems to be successful at the mid-term follow-up in mild hip dysplasia patients. The most important point was that avascular necrosis was not seen in any of the patients with this technique.

Keywords: Developmental hip dysplasia; Pelvic osteotomy; Avascular necrosis; Hip joint; Reduction

\section{Özet}

Bu çalışmanın amacı kalça ekleminde hafif displazisi olan hastalarda açı redüksiyon olmadan Pembersal ve femoral osteotominin orta dönem klinik ve radyografik sonuçlarını göstermektir. Bu vaka serisi Ocak 2014 ve Haziran 2020 tarihleri arasında açık redüksiyon olmadan Pembersal ve femoral osteotomi uygulanan 13 Gelişimsel Kalça Displazisi (GKD) hastasını (13

kalça) içermektedir. Hastaların 12' si kız (\%93) ve 1' i erkek (\%8), cerrahi sırasındaki ortalama yaş 24.2 \pm 9.40 ay (aralık: 17-51 ay) ve ortalama takip süresi ise $31.4 \pm 13.2$ ay idi (aralık: $12-49$ ay). Ortalama asetabular indeks son takipte $36.6^{\circ} \pm 4.87^{\circ}$ (aralık: $\left.30^{\circ}-46^{\circ}\right)$ den önemli derecede düşerek $18^{\circ} \pm 1.41^{\circ}$ (aralık: $15^{\circ}$-210) geriledi $(\mathrm{p}<0.001)$. Hiçbir hastada avasküler nekroz görülmedi. Elde edilen bu sonuçlar bu tarz cerrahi girişimin hafif kalça displazili hastalarda orta dönem takiplerde başarılı olduğunu göstermektedir. En önemli nokta ise bu teknikle hiçbir hastada avasküler nekrozgörülmemiş olmasıdır.

Anahtar Kelimeler: Gelişimsel kalça displazisi; Pelvik osteotomi; Avasküler nekroz; Kalça eklemi; Redüksiyon 


\section{Introduction}

Developmental Dysplasia of the Hip (DDH) is one of the most important diseases that can cause devastating complications if not treated early. At a young age the treatment is conservative, but if the DDH is diagnosed late, surgical treatment will be most appropriate for successful results. Surgical options include the release of soft tissues (eg: adductor tenotomies, iliopsoas tenotomies, and etc.) acetabular and/or femoral osteotomies, or both procedures (combined bone and soft tissue procedures). The goal in the treatment of DDH is to achieve and maintain stable and concentric reduction of the hip joint. Once the reduction is maintained, the acetabular development will improve over time (1). Many treatment methods have been reported in the literature for DDH patients aged 1 - 3 years, including closed reduction alone, open reduction alone, and open reduction with acetabular and/or pelvic osteotomies $(2,3)$. To be able to achieve concentric reduction in surgical treatment of $\mathrm{DDH}$, the hip joint should be opened and the obstacles to reduction, which are the hypertrophic ligamentum teres, transverse acetabular ligament, and pulvinar, must be removed, then the elongated hip capsule should be plicated. The aim of this study was to investigate the effectiveness of a surgical procedure, which was without open reduction while performing bony procedures, and the results of those patients at the midterm follow-up.

\section{Materials and Methods}

Institutional review board approval for this study was obtained from the Institution Ethics Committee (Number:2020-12-899). This retrospective case control study included a total of 13 patients (13 hips) (Table 1), who were treated for DDH at our university hospital between January 2014 and June 2020 . The inclusion criteria were as follows; patients with an interrupted Shenton-Menard line and high acetabular index (above double standard deviation/ according to Tönnis criteria) values on pelvis anterior-posterior radiograph (4). Exclusion criteria were as follows; completely dislocated DDH patients, patients with known neuromuscular disease, genetic and chromosomal disorders, and patients who had previous interventions such as closed reduction under anaesthesia or any kind of surgery for DDH. Pembersal and femoral osteotomy were performed in patients, whose preoperative radiographs showed an improved Shenton-Menard line and concentric reduction achieved with abduction and internal rotation manoeuvre of the hip joint. The same bony procedure was performed with open reduction in patients who did not meet the criteria mentioned above. The surgical intervention was made with the Smith Peterson approach in all patients. In all surgeries, first a femoral derotational osteotomy was performed, followed by Pembersal osteotomy. Initially, the femoral osteotomy was performed through a separate direct lateral approach. All patients had a 10-15 degree derotation procedure and varus osteotomy. Derotation was performed in the same way in all patients but varus degree correction was performed according to the preoperative radiograph for each patient. The osteotomy was then fixed with a Harris Muller plate and screws. The Pembersal pelvic osteotomy was then performed using an osteotome under image intensifier control. A tri-cortical iliac graft was harvested for the osteotomy area, and no internal fixation device was used to fix the graft on the osteotomy side (Fig. 1- 3). The affected hip joint capsule was not opened and adductor and iliopsoas tenotomies were not performed in any of the cases. After surgery, a hip spica cast was applied to all patients for 6 weeks with the hip positioned in $90^{\circ}$ flexion, $60^{\circ}$ abduction, and $10^{\circ}$ internal rotation. The cast was replaced with a Denis Brown splint for an additional 6 weeks. Weight-bearing was not permitted on the affected extremity during that time. The acetabular index values were measured on pelvis radiography preoperatively and at the final follow-up examination. The pelvis radiographs were evaluated according to the presence or absence of avascular necrosis of the hip joint. The acetabular index results were statistically analyzed. 
Table 1. The demographic information of patients

\begin{tabular}{|c|c|c|c|c|c|c|}
\hline $\begin{array}{c}\text { Number } \\
\text { of } \\
\text { patient }\end{array}$ & Sex & $\begin{array}{c}\text { Side of } \\
\text { procedure }\end{array}$ & $\begin{array}{l}\text { Age of } \\
\text { the } \\
\text { patients } \\
\text { at initial } \\
\text { surgery } \\
\text { (months) }\end{array}$ & $\begin{array}{c}\text { Acetabular } \\
\text { angle }\left({ }^{0}\right) \text { at } \\
\text { initial } \\
\text { surgery }\end{array}$ & $\begin{array}{c}\text { Acetabular } \\
\text { angle }\left(^{0}\right) \text { at } \\
\text { final follow- } \\
\text { up }\end{array}$ & $\begin{array}{c}\text { Follow-up } \\
\text { time } \\
\text { (months) }\end{array}$ \\
\hline 1 & Female & $\mathrm{L}$ & 20 & 34 & 18 & 33 \\
\hline 2 & Female & $\mathrm{R}$ & 17 & 36 & 19 & 48 \\
\hline 3 & Female & $\mathrm{R}$ & 34 & 33 & 17 & 18 \\
\hline 4 & Female & $\mathrm{R}$ & 19 & 37 & 18 & 43 \\
\hline 5 & Female & $\mathrm{R}$ & 28 & 41 & 15 & 34 \\
\hline 6 & Female & L & 22 & 45 & 17 & 20 \\
\hline 7 & Female & L & 17 & 46 & 18 & 46 \\
\hline 8 & Female & $\mathrm{R}$ & 21 & 38 & 18 & 24 \\
\hline 9 & Female & L & 19 & 37 & 17 & 49 \\
\hline 10 & Male & $\mathrm{L}$ & 51 & 34 & 19 & 27 \\
\hline 11 & Female & L & 19 & 30 & 21 & 14 \\
\hline 12 & Female & $\mathrm{L}$ & 26 & 32 & 19 & 40 \\
\hline 13 & Female & $\mathrm{R}$ & 21 & 33 & 18 & 12 \\
\hline
\end{tabular}

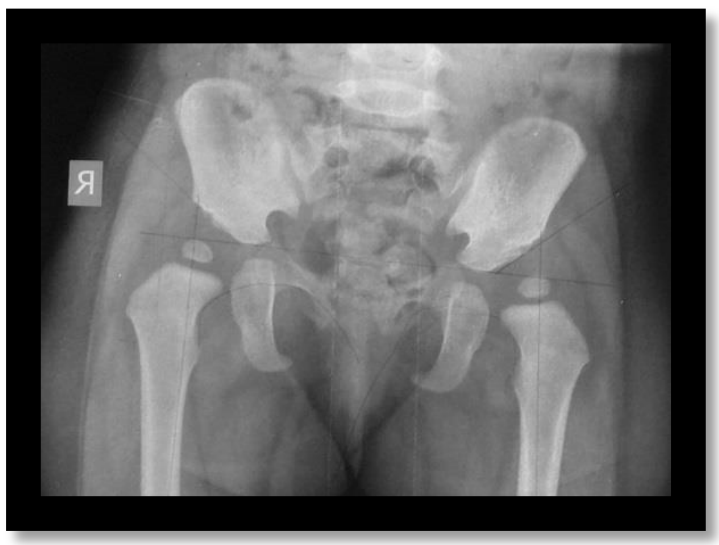

Figure 1. Preoperative anterior-posterior pelvis radiograph (patient number: 9). Bilateral hip dysplasia is shown on $\mathrm{x}$-ray image. Acetabular dysplasia was more on the left side compared to right hip.

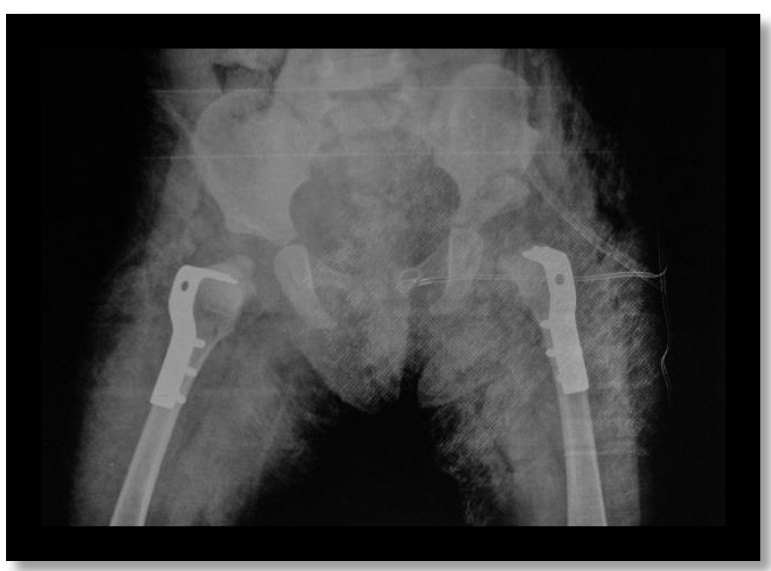

Figure 2. The anterior-posterior pelvis radiograph in a cast at immediate post-operative time period is shown. The acetabular osteotomy line on the left side is shown. Left hip underwent to surgery (Pembersal osteotomy+ varus derotational osteotomy) at 19 months of age. Varus derotational osteotomy performed at the same time for the right hip. 


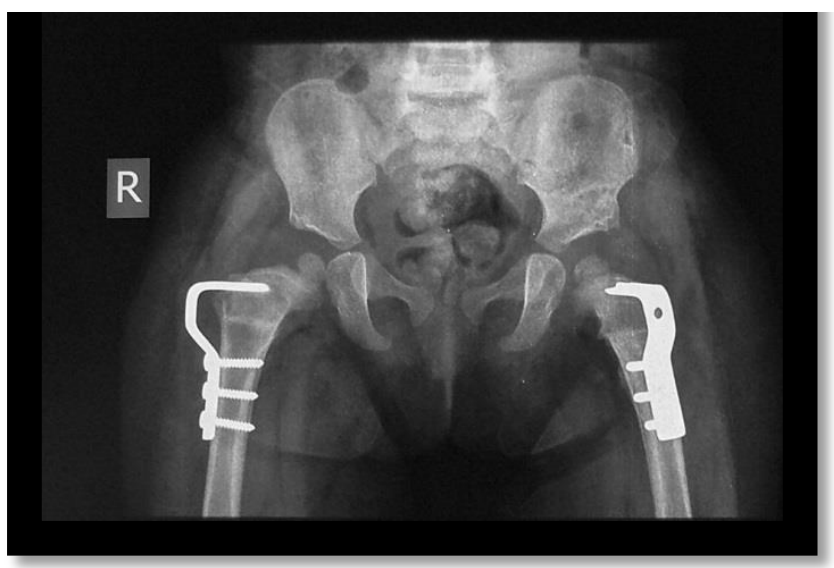

Figure 3. Postoperative radiograph at 10 months.

\section{Statistical Analysis}

Data obtained in the study were analyzed statistically using IBM SPSS vn. 21.0 software. Continuous data were given as mean \pm standard deviation (SD) values and categorical data as number(n) and percentage (\%). Conformity of the data to normal distribution was assessed with the Shapiro Wilk test. The Student's t-test was used in groups showing normal distribution to compare the changes over time. A value of $\mathrm{p}<$ 0.05 was considered statistically significant.

\section{Results}

Evaluation was made of 13 patients, comprising 12 females (92\%) and 1 male $(8 \%)$ with mean age at the time of surgery of 24.2 \pm 9.40 months (range: 17-51 months). All the patients underwent one stage hip surgery for DDH without open reduction. The right hip was affected in 6 patients (46\%), and the left hip in 7 (54\%). Bilateral hip involvement present in 4 patients, all of whom had the same procedure on one side only, and open surgery was performed on the other side. All patients had a minimum of one year of followup. The mean follow-up period was $31.4 \pm 13.2$ months (range: 12-49 months). A statistically significant decrease was determined in the mean acetabular index from $36.6^{\circ} \pm 4.87^{0}$ (range: $30^{\circ}-46^{\circ}$ ) preoperatively to $18^{\circ} \pm 1.41^{0}$ (range: $15^{0}-21^{0}$ ) at the final follow-up examination $(\mathrm{p}<0.001)$. No postoperative complications developed in any of the patient, such as surgical site infection, wound infection, neurovascular impairment, or recurrence of DDH.

\section{Discussion}

Developmental dysplasia of the hip (DDH) is a devastating problem worldwide. Failure to treat DDH patients may lead to gait abnormalities, limitation of range of motion of the hip, pain and osteoarthritis at an early age. If it is diagnosed and treated early, many future complications will be prevented. DDH can be treated effectively before walking age using conservative treatment methods or soft tissue procedures (5). However, with increasing age, additional bony interventions are needed to maintain a concentric and stable reduction. The goal in the treatment of DDH is to achieve concentric reduction and to maintain it throughout the lifetime of the patient. However, many complications can occur after surgical procedures. Avascular necrosis (AVN) and residual acetabular dysplasia are the two main complications of DDH treatment. Of these, AVN of the hip joint is encountered most often after performing DDH treatment with conservative or surgical methods (6-9). It is thought that open reduction could increase the AVN risk (6). Hence, in this series surgical intervention without open reduction was performed. Treatment of DDH varies depending on the age of patient. As the patient reaches walking 
age and older, treatment becomes problematic and controversial (10). Many authors have reported success with a single-stage procedure consisting of open reduction, capsulorrhaphy, femoral shortening and pelvic osteotomy (1114). In this series the surgeries were performed as in the past, but without open reduction and femoral shortening. In older children with DDH, a pelvic or femoral osteotomy may be necessary in addition to open reduction to solve the problem of acetabular dysplasia. In the past, the debate was about whether concomitant osteotomies should be performed in children after walking age (15-17). As the DDH patient becomes older, contractures of the capsule and musculotendinous structures surrounding the hip joint prevent reduction of the femoral head into the acetabulum, and may produce pressure on the femoral head during or after reduction, leading to ischaemia. Consequently, AVN can occur because of ischaemia. It is well known that AVN of the femoral head is a major devastating and severe complication associated with treatment of DDH. In the current patients, there were no fully dislocated hips. Therefore, open reduction was not performed, but only reduction with Pembersal and femoral osteotomy, as concentric reduction had been observed to have been achieved with abduction and internal rotation manoeuvre on the preoperative pelvis radiograph. It can be considered that ANV was not observed in this study group in the mid-term period as the reduction had been applied without an open procedure. Open reduction might be related with AVN. Roposch et al. (7) reported that hips with AVN had abnormal indices of acetabular remodelling at follow-up, and AVN of the femoral head was found to inhibit the acetabular remodelling. Another study stated that patients who underwent open reduction combined with osteotomies, redislocation, or required secondary reconstructive procedures after initial surgery were at higher risk of the development of AVN. The rate of AVN was reported as $40 \%$ in that study (6). AVN has been reported at very high rates in the literature, whereas in the current study, although a small number of patients were evaluated, the AVN rate was zero, at least in the mid-term. That AVN did not develop following this kind of procedure can be considered of the greatest importance. To the best of our knowledge, this is the first report in the English literature to have evaluated the results of DDH patients who have undergone combined acetabular and femoral osteotomy without open reduction.

Carvalho Filho et al. (Salter ostetotomy) found the Acetabular Index (AI) angle to be mean $39^{\circ}$ preoperatively and $22^{\circ}$ postoperatively (18). In another study, Rocha et al. (Salter + femoral shortening) reported the preoperative values as right side $43.3^{\circ}$ and left side $42.1^{\circ}$, and the postoperative values regressed to $31.57^{\circ}$ and $30.36^{\circ}$, respectively (19). Yagmurlu et al. (Salter or Triple osteotomy+ femoral shortening) found that AI values decreased from $37.8^{0}$ preoperatively to $21.2^{0}$ after the surgery (20). Abdullah et al. (Salter or Dega osteotomy+ femoral shortening) showed decreasing AI values from $44^{0}$ to $23^{\circ}(21)$. Chang et al. (Salter osteotomy) reported a mean preoperative AI of $35.4^{0}$, and at 10 years postoperatively, this value was $12.6^{0}$ (22). Kotzias et al. (Salter+ femoral shortening) reported mean AI angle of $38^{\circ}$ and mean late postoperative value of $18.2^{\circ}$ (23). The average AI correction has been reported to be approximately $18^{\circ}$ after surgery (Salter, Dega osteotomy + femoral shortening) (24). Of these studies, femoral shortening was not performed in addition to pelvic osteotomy in only two studies and between $12^{\circ}$ and $23^{\circ}$ AI correction was achieved at the most recent follow-up. In all the above-mentioned studies, the decrease in AI values postoperatively was found to be statistically significant. Although concomitant open reduction and performing more complex bony procedures than those of the current study, these AI (approximately $18^{\circ}$ correction) values were the same as in the current study group. It can be considered that increased stripping of the soft tissue during surgery, and forceful positioning of the hip joint to maintain hip reduction may also have contributed to AVN of the femoral head. Although some authors have advocated open reduction in patients older than 24 months $(25,26)$, it has been reported that open surgery is a risk factor for $\operatorname{AVN}(6,27,28)$. El-sayed et al. (24) reported success in neglected DDH 
patients at walking age, with open reduction with either Salter or Dega osteotomies. However, the procedure applied to those patients was different from that of the current study, such as adductor tenotomy, capsulorrhaphy and opening the hip capsule. In addition, AVN was found in 9 of 87 patients at the final follow-up examination (24). Kotzias et al. (23) reported AVN in 15 of 42 hips. In a review by Kothari et al. (29), open reduction was reported to have a lower risk of AVN than open reduction combined with pelvic and femoral osteotomy (4\% versus 24\%). However, no significant difference was seen in the comparisons of open reduction with either pelvic (17\%) or femoral osteotomy $(18 \%)$. It was concluded that open reduction with concomitant pelvic osteotomy is the most appropriate option to provide durable results with the lowest risk of AVN, although other studies $(20,22)$ in the literature have reported AVN during the follow-up period. In contrast to these results with open surgery, in a recent study, closed reduction and hip spica cast were used for DDH patients (age: 24-36 months). However, but $5 \%$ AVN was seen to have developed at the latest follow-up examination (8). An important study in the literature by Roposch reported dramatic results of AVN in 86 of 118 patients (73\%) treated with open or closed reduction with a mean follow-up period of 8 years (range: 1-19 years). This was a huge rate of AVN and it can be considered that AVN might be related with open reduction. The AVN results in the current study were zero in the mid-term period, and these results might be related with not performing open reduction. Although the radiographic appearance of AVN in the femoral head occurs within the first or the second year following surgery, lateral physeal growth disturbance can appear at any time until maturity (30). Therefore, these results must be considered as preliminary results as they are only the mid-term results.

Limitations of this study included the following; 1) the retrospective design of the study, 2) the small sample size, 3 ) the followup period was not long enough to provide an adequate long-term evaluation of this procedure, 4) because of the given mid-term results, all the patients were not able to be followed until skeletal maturity, which is of clinical importance and radiographic changes, especially for the AVN, tend to vary over time 5) follow-up of the patients until maturity is needed to determine the permanent effects of the surgical procedure.

\section{Conclusions}

According to our experience, we strongly recommend this surgical procedure, which was femoral and Pembersal osteotomy without open reduction for the treatment of DDH patients in the walking age group. A longer follow-up time is certainly necessary to determine AVN of the femoral head in the long-term following this kind of surgical procedure. Therefore, there is a need for further multi-centre studies with a larger number of patients to clarify and follow the long-term results of this procedure.

\section{REFERENCES}

1. Akagi S, Tanabe T, Ogawa R. Acetabular development after open reduction for developmental dislocation of the hip: 15-year follow-up of 22 hips without additional surgery. Acta Orthop Scand. 1998;69:17-20.

2. Huang S-C, Wang J-H. A comparative study of nonoperative versus operative treatment of developmental dysplasia of the hip in patients of walking age. J Pediatr Orthop. 1997;17:181-8.

3. Berkeley ME, Dickson JH, Cain TE, Donovan MM. Surgical therapy for congenital dysplasia of the hip in patients who are twelve to thirty-six months old. J Bone Joint Surg (Am). 1984;66A:412-20.

4. Tönnis D. Normal values of the hip joint for the evaluation of X-rays in children and adults. Clin Orthop Relat Res. 1976;119:39-47.

5. Herring J. Developmental dysplasia of the hip. In: Herring J (editor). Tachdjian's pediatric orthopaedics. Philadelphia, WB Saunders, 2008, pp 637-770.

6. Pospischill R, Weninger J, Ganger R, Altenhuber J, Grill F. Does open reduction of the developmental dislocated hip increase the risk of osteonecrosis? Clin Orthop Relat Res. 2012;470:250-60.

7. Roposch A, Ridout D, Protopapa E, Nicolaou N, Gelfer Y. Osteonecrosis complicating developmental dysplasia of the hip compromises 
subsequent acetabular remodeling._Clin Orthop Relat Res. 2013;471:2318-26.

8. Li Y, Guo Y, Shen X, Liu H, Mei H, Xu H, Canavese F; Chinese Multi-center Pediatric Orthopedic Study Group (CMPOS). Radiographic outcome of children older than twenty-four months with developmental dysplasia of the hip treated by closed reduction and spica cast immobilization in human position: a review of fifty-one hips. Int Orthop. 2019;43:1405-11.

9. Roposch A, Liu LQ, Offiah AC, Wedge JH. Functional outcomes in children with osteonecrosis secondary to developmental dysplasia of the hip. J Bone Joint Surg Am. 2011;93:e145.

10. Schoenecker PL, Strecker WB. Congenital dislocation of hip in the children. Comparison of the effects of femoral shortening and of skeletal traction in the treatment. $J$ Bone Joint Surg Am. 1984;66:21-7.

11. Karakaş ES, Baktir A, Argün M, Türk CY. Onestage treatment of congenital dislocation of the hip in older children. $J$ Pediatric Orthop. 1995; 15:330-6.

12. Klisic P, Jankovic L, Basara V. Long-term results of combined operative reduction of the hip in older children. J Pediatric Orthop. 1988;8:532-4.

13. Agarwal A, Rastogi P. Clinicoradiological outcomes following pembersal acetabular osteotomy for developmental dysplasia of hip in young children: A series of 16 cases followed minimum 2 years. $J$ Clin Orthop Trauma. 2021;23:101669.

14. Stuart L. Weinstein, Scott J. Mubarak and Dennis R. Wenger. Developmental Hip Dysplasia and Dislocation: Part I $J$ Bone Joint Surg Am. 2003;85:1824-32.

15. Lindstrom JR, Ponseti IV, Wenger DR. Acetabular development after reduction in congenital dislocation of the hip. $J$ Bone Joint Surg Am. 1979;61:112-8.

16. Salter RB. Role of innominate osteotomy in the treatment of congenital dislocation and subluxation of the hip in the older child. $J$ Bone Joint Surg Am. 1966;48:1413-39.

17. Salter RB. The classic: innominate osteotomy in the treatment of congenital dislocation and subluxation of the hip by Robert B. Salter, J Bone Joint Surg (Brit) 43B:3:518, 1961. Clin Orthop Relat Res. 1978;137:2-14.

18. Carvalho Filho $\mathrm{G}$, Chueire AG, Ignácio $\mathrm{H}$, Carneiro MO, Neto JF, Canesin AC. Tratamento cirúrgico da luxac,ãocongênita do quadril pós marcha: reduc,ão aberta e osteotomia de Salter. Acta Ortop Bras. 2003;11:42-7.

19. Rocha VL, Thomé AL, Castro DL, Oliveria LZ, Moraes FB. Avaliac,ão clínica e radiológica após procedimento de Salter e Ombrédanne na displasia de desenvolvimento do quadril. Rev Bras Ortop. 2011;46:650-5.

20. Yagmurlu MF, Bayhan IA, Tuhanioglu U, Kilinc AS, Karakas ES. Clinical and radiological outcomes are correlated with the age of the child in single-stage surgical treatment of developmental dysplasia of the hip. Acta Orthop Belg. 2013;79:159-65.

21. Abdullah ES, Razzak MY, Hussein HT, El-Adwar KL, Youssef AA. Evaluation of the results of operative treatment of hip dysplasia in children after the walking age. Alexandria $J$ Med. 2012;48:115-22.

22. Chang CH, Kao HK, Yang WE, Shih CH. Surgical results and complications of developmental dysplasia of the hip - one stage open reduction and Salter's osteotomy for patients between 1 and 3 years old. Chang Gung Med J. 2011;34:84-92.

23. Kotzias Neto A, Ferraz A, Bayer Foresti F, Barreiros Hoffmann R. Bilateral developmental dysplasia of the hip treated with open reduction and Salter osteotomy: analysis on the radiographic results. Rev Bras Ortop. 2014;49:350-8.

24. El-Sayed M, Ahmed T, Fathy S, Zyton H. The effect of Dega acetabuloplasty and Salter innominate osteotomy on acetabular remodeling monitored by the acetabular index in walking DDH patients between 2 and 6 years of age: shortto middle-term follow-up. $J$ Child Orthop. 2012;6:471-7.

25. Arrest NA, Ramachandran M, Paterson MJMH, Barry M. Paediatric orthopaedics in clinical practice. London, Springer-Verlag, 2016.

26. Kelly DM. Congenital and developmental anomalies of the hip and pelvis. In: Canale ST, Beaty JH (ed). 12th edn. Campbell's operative orthopaedics. Elsevier Mosby, Philadelphia, 2013, pp 1079-117.

27. Firth GB, Robertson AJ, Schepers A, Fatti L. Developmental dysplasia of the hip: open reduction as a risk factor for substantial osteonecrosis. Clin Orthop Relat Res. 2010;468:2485-94.

28. Wang YJ, Yang F, Wu QJ, Pan SN, Li LY. Association between open or closed reduction and avascular necrosis in developmental dysplasia of the hip: a PRISMA-compliant meta-analysis of observational studies. Medicine. 2016;95:e4276.

29. Kothari A, Grammatopoulos G, Hopewell S, Theologis T. How Does Bony Surgery Affect Results of Anterior Open Reduction in Walkingage Children With Developmental Hip Dysplasia? Clin Orthop Relat Res. 2016;474:1199-208.

30. Kim HW, Morcuende JA, Dolan LA, Weinstein SL. Acetabular development in developmental dysplasia of the hip complicated by lateral growth disturbance of the capital femoral epiphysis. $J$ Bone Joint Surg Am. 2000;82-A:1692-700. 